\title{
Rubella antibody determination from heparinised finger-tip blood by single radial haemolysis and enzyme immunoassay
}

\author{
ANTTI VAHERI, PERTTI VÄÄNÄNEN, EEVA-MARJATTA SALONEN, AND \\ JUKKA SUNI* \\ From the Department of Virology, University of Helsinki, Haartmaninkatu 3, SF-00290 Helsinki 29, and \\ the * Department of Clinical Virology, Municipal Bacteriology Laboratory, Aurora Hospital, \\ Nordenskjöldinkatu 20, SF-00250 Helsinki 25, Finland
}

SUMmaRY Rubella antibodies were determined by single radial haemolysis (SRH) and a micromodification of enzyme immunoassay (EIA) of samples of heparinised finger-tip blood or plasma collected into transportable vials, and the results were compared with antibody titres obtained from conventional samples of venous serum. The antibody titres of finger-tip specimens gave a high correlation with those of venous serum. For SRH only $5 \mu \mathrm{l}$ of heat-inactivated finger-tip plasma was needed, and for EIA only a single dilution, 1:100, in duplicate, of heparinised finger-tip plasma or whole blood was sufficient. The minimal inconvenience in sample collection makes the finger-tip test particularly suitable for large-scale immunity screening when assessing the need for, or efficacy of, rubella vaccination.

Measurement of viral antibodies on a large scale is needed today in testing for rubella immunity, particularly when assessing the need for, or efficacy of, vaccination. ${ }^{2}$ The rubella haemagglutination inhibition test (HI), ${ }^{3}$ which for years has been the only practical method in screening for rubella antibodies, has several drawbacks. The serum samples have to be pretreated to remove nonspecific serum inhibitors and haemagglutinins, and serial dilutions are required which make the $\mathrm{HI}$ test a relatively tedious and insensitive way of determining rubella antibodies. Currently, the HI test is being replaced by the single radial haemolysis (SRH) test, ${ }^{4-6}$ also known as the haemolysis-in-gel test, and enzyme or radioimmunoassays (EIA and RIA), ${ }^{\text {7-10 }}$ more sensitive and reproducible procedures which permit reliable quantitation of serum rubella antibodies using either undiluted heat-treated serum (SRH) or a single dilution of untreated serum (EIA and RIA). In these assays, only small amounts of serum are needed. We now report that both SRH and EIA may be used to measure rubella antibodies from finger-tip blood. The methods described below appear to be especially well suited for screening rubella virus antibodies in large populations.

Received for publication 10 December 1979

\section{Material and methods}

BLOOD SAMPLES

Samples of venous blood were obtained from healthy individuals using needle and syringe and were clotted to obtain serum. Samples of finger-tip blood were collected using disposable blood lancets (SeraSharp $^{R}$, Propper Co, Long Island City, NY, USA) and disposable $300 \mu$ l capillary vessels coated with lithium heparin (No. 443, W. Sarstedt, Nümbrecht, West Germany) equipped with stoppers and a carrier vessel. Plasma was taken from the heparinised blood with a micropipette after sedimentation of the blood cells (with or without the use of a table centrifuge).

\section{RUBELLA ANTIBODY ASSAYS}

The SRH tests were performed using commercially obtained plates (OriVir ${ }^{\mathrm{R}}$ Rubella, Orion Diagnostica, Helsinki, Finland) containing in agarose gel purified rubella virus coupled with $\mathrm{CrCl}_{3}$ to chicken erythrocytes, and guinea-pig complement as described. ${ }^{6}$ A small aliquot of serum or plasma was incubated for 15 minutes at $56^{\circ} \mathrm{C}$, and $5 \mu \mathrm{l}$ of the undiluted samples was applied per well. The results, the diameters of the haemolytic zones, were recorded after an incubation of 20 hours at $37^{\circ} \mathrm{C}$. 
ENZYME IMMUNOASSAY

A micromethod for rubella EIA was used as described. ${ }^{11}$ Sucrose gradient purified rubella virus grown in suspension cultures of BHK21/13S cells was used as EIA antigen and was adsorbed on flatbottomed polystyrene microplates. A $75 \mu$ l volume of the specimens, diluted in duplicate in phosphate buffered saline containing $0.02 \% \mathrm{v} / \mathrm{v}$ Tween 20 (polyoxyethylene sorbital monolaureate), was added, and after 2 hours' incubation at $37^{\circ} \mathrm{C}$ the plates were washed and incubated overnight with commercially obtained alkaline phosphatase-conjugated antihuman IgG (Orion Diagnostica) with $0.2 \% \mathrm{w} / \mathrm{v}$ $p$-nitrophenyl phosphate disodium salt in diethanolamine- $\mathrm{MgCl}_{2}$ as the substrate. After 30 minutes at $37^{\circ} \mathrm{C}$ the enzyme reaction was stopped by adding $1 \mathrm{M} \mathrm{NaOH}$, and the absorbances at $405 \mathrm{~nm}$ were determined using a spectrophotometer measuring through each well bottom (Titertek ${ }^{\mathrm{R}}$ Multiskan, Eflab Oy, Helsinki, Finland). Polystyrene microwells coated with control antigen prepared from uninfected BHK21/13S cultures gave no reaction $\left(E_{405}<0.050\right)$ with any of the sera tested.

\section{Results}

Rubella antibodies were determined with the SRH test and EIA from venous serum, from heparinised finger-tip plasma, and from heparinised finger-tip whole blood from a number of healthy individuals. As shown in Fig. 1, the results obtained in the SRH test from heparinised finger-tip plasma were equal to those obtained from venous serum. It was not possible to use whole finger-tip blood (treated at

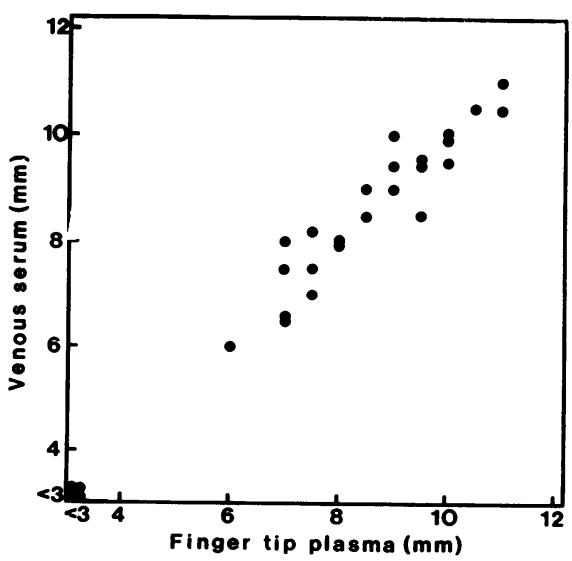

Fig. 1 Comparison of rubella antibody levels in samples of venous serum and heparinised finger-tip plasma using the single radial haemolysis test. Regression analysis gave the correlation coefficient $(r)=0.989$. $56^{\circ} \mathrm{C}$ for 15 minutes to inactivate the intrinsic complement) in the SRH test because total haemolysis in the sample obscured detection of the antibodyinduced haemolytic zones.

In EIA samples with various amounts of rubella antibodies were initially tested in duplicate at several dilutions-1:50, 1:100, 1:200, and 1:400. A dilution of $1: 100$ was chosen for subsequent assays, since this dilution of both finger-tip plasma, heparinised blood, and venous serum gave for most samples an absorbance value in the linear portion of the titration curve. This dilution gave a reliable measure of the antibody level (Fig. 2). Samples of finger-tip plasma gave by EIA absorbance values similar to those obtained from venous sera. As expected, the absorbances from whole blood were somewhat lower (Fig. 2). The samples negative in

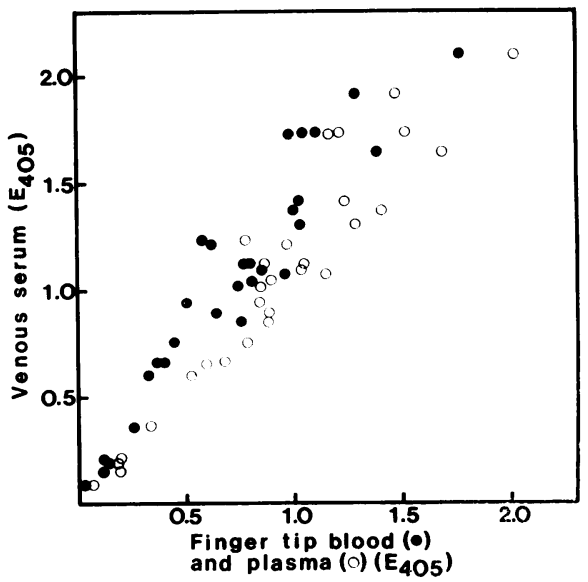

Fig. 2 Comparison oJ rupella antibody levels by enzyme immunoassay (EIA) in samples of venous serum and of heparinised finger-tip blood and plasma. Correlation coefficients were between venous serum and finger-tip blood $(r)=0.945$ and between venous serum and finger-tip plasma $(r)=0.949$.

the SRH test $(<3 \mathrm{~mm}$ ) were also negative in EIA $\left(E_{405}<0.25\right)$. When samples of whole blood were analysed, small amounts of erythrocyte-derived red material inevitably adhered to the virus-coated microwell bottoms but did not interfere with the spectrophotometric reading of the yellow reaction product in EIA. To evaluate further the applicability of heparinised whole finger-tip blood, samples were frozen and thawed repeatedly to disrupt the blood cells. This resulted in haemolysis and gave by EIA absorbance values consistently about $20 \%$ lower than those obtained from fresh heparinised finger-tip blood where no haemolysis was detectable. 


\section{Discussion}

The new serological procedures such as the SRH test and EIA have made it possible to measure viral antibodies from small sample volumes. Our results show that the immunity status to rubella may be determined reliably by either method from finger-tip blood. The procedures described were intended to simplify collection of the samples and to make feasible the ambulatory collection of samples in, for example, maternity centres, health care centres, working premises, or schools. Finger-tip blood, as well as heel-tip blood from infants, may be obtained with minimal inconvenience to the donor, which should increase motivation in screening programmes. Essential for ambulatory collection are easily transportable sample tubes, such as the disposable capillary vessels used in this study. Transportation of whole blood may lead to partial haemolysis in the samples; we found that haemolysis did not significantly interfere in the EIA test, and even in the SRH test partial haemolysis could be tolerated. In conclusion, finger-tip blood samples, together with sensitive serological methods such as SRH, EIA, or RIA, make immunity screening programmes more feasible and convenient for both the individual and the laboratory.

We thank Mrs Liisa Pitkänen for expert technical assistance. This work was supported by the Association of Finnish Life Insurance Companies.
References

${ }^{1}$ Goldwater PN, Quiney JR, Banatvala JE. Maternal rubella at St. Thomas' Hospital-is there a need to change British vaccination policy? Lancet 1978;2:1298-300.

${ }^{2}$ Schiff GM, Rauh JK, Young B, Trible S, Rotte T, Schigg BE. Rubella-vaccinated students-follow-up in a publicschool system. J Am Med Assoc 1978;240:2635-7.

${ }^{3}$ Stewart G, Parkman PD, Hopps HE, Douglas RD, Hamilton JP, Meyer HM. Rubella-virus haemagglutination test. $N$ Engl J Med 1967;276:554-7.

4 Schild GC, Oxford JS, Virelizier JK. Immunity to influenza. Dev Biol Stand 1975;28:253-72.

5 Morgan-Capner P, Pullen HJM, Pattison JE, Bidwell DE, Bartlett A, Voller A. A comparison of three tests for rubella antibody screening. J Clin Pathol 1979;32:542-5.

- Väänänen P, Vaheri A. Hemolysis-in-gel test in immunity surveys and diagnosis of rubella. J Med Virol 1979; 3:245-52.

${ }^{7}$ Kalimo KOK, Meurman OH, Halonen PE, Ziola BR, Viljanen MK, Granfors K, Toivanen P. Solid-phase radioimmunoassay of rubella-virus immunoglobulin-G and immunoglobulin-M antibodies. J Clin Microbiol 1976;4:117-23.

${ }^{8}$ Gravell M, Dorsett PH, Gutenson O, Ley AC. Detection of antibody to rubella-virus by enzyme-linked immunosorbent assay. J Inf Dis 1977;136:300-3.

${ }^{9}$ Leinikki PA, Shekarchi I, Dorsett P, Sever JL. Enzymelinked immunosorbent assay determinations of specific rubella antibody levels in micrograms of immunoglobulin-G per milliliter of serum in clinical samples. J Clin Microbiol 1978;8:419-23.

${ }^{10}$ Vejtorp M. Enzyme-linked immunosorbent assay for determination of rubella IgG antibodies. Acta Path Microbiol Scand, Section B, 1978;86:387-92.

11 Vaheri A, Salonen E-M. Evaluation of solid-phase enzyme-immunoassay procedure in immunity surveys and diagnosis of rubella. $J$ Med Virol (in press).

Requests for reprints to: Dr Antti Vaheri, Department of Virology, University of Helsinki, Haartmaninkatu 3, SF-00290 Helsinki 29, Finland. 